\title{
The Legal Politics of the Inquiry Rights of the House of Representatives Post 1945 Constitutional Amendment
}

\author{
Hananto Widodo ${ }^{1} \quad$ Sudarsono $^{2} \quad$ Moh Fadli $^{3} \quad$ Tunggul Anshari $\mathrm{SN}^{3}$ \\ 1.Doctorate Candidate of Law Faculty, Brawijaya University, Malang, Indonesia and Lecturer at the Faculty of \\ Social Cciences and Law of the State University of Surabaya \\ 2.Professor on Administrative Law of Law Faculty, Brawijaya University, Malang, Indonesia. \\ 3.Postgraduate Program of Law Faculty, Brawijaya University, Malang, Indonesia.
}

\begin{abstract}
The legal politics of the inquiry rights of the House of Representatives post 1945 constitutional amendment is to strengthen the position and function of the House of Representatives. The strengthening of the House of Representatives function in the regulation of inquiry rights is proven by the existence of regulation of the function of the House of Representatives' supervision of the inquiry rights in Article 20 A paragraph (2) second amendment o 1945 constitution. Prior to 1945 constitutional amendment, the oversight function of the House of Representatives was only regulated in the description of the 1945 Constitution. The oversight function of the House of Representatives regulated in the description of the 1945 Constitution was still in general. The regulation of the House of Representatives' function in the description of the 1945 Constitution does not explicitly mention the types of supervision from the House of Representatives, inquiry rights, interpellation rights or the right to express opinions. One of the objectives of People's Consultative Assembly in conducting the amendment of the 1945 Constitution was to emphasize the presidential system; the 1945 Constitution prior to amendment does not follow a presidential system purely. The choice to reinforce the presidential system is to build a stable government. The regulation of the inquiry rights of the House of Representatives is considered by some Indonesian constitutional law experts to be counterproductive if it is associated with the purpose of amending the 1945 Constitution to reinforce the presidential system. Some experts argue that inquiry rights are common in countries that adopt a parliamentary system, because the right of inquiry is one of the main characteristics of a parliamentary system, whereas in a country that adheres to a presidential system the inquiry rights is unusual. The methods used in this paper include the comparative method. The comparison with the United States, which is the first country the first country to adopt a presidential system, then it can be seen that in the constitutional system in the United States also recognizes the authority of the Congress to conduct a supervision on the government's performance or known as Congressional Oversight.
\end{abstract}

Keywords : The Legal Politics, The Inquiry Rights, Post 1945 Constitutional Amendment

DOI: $10.7176 / \mathrm{JLPG} / 85-14$

Publication date:May $31^{\text {st }} 2019$

\section{I.INTRODUCTION}

The authority without a supervision will make the authority tend to be deviant. Lord Acton stated that Authority tends to corrupt; absolute authority tends to corrupt absolutely. Therefore, the supervision on an authority is the main requirement of the functioning of a democratic system in a country.

The most important authority is to obtain a supervision is the executive authority. Executive authority is the most extensive authority compared to the other two branches of authority, namely legislative and judicial. Legislative authority only includes the authority of law formation, oversight authority, and budgetary authority. Similarly, with juridical authority only includes the authority to process a case in the court and sentence. Meanwhile, the executive authority includes almost all aspects of society's life, from licensing, correspondence, police, prosecution and so on.

The functioning of supervision on executive by both legislative and the court will be highly determined by the legal political direction of the country that is constitution. The constitution as a political-legal basis of a country is based on the argument that the constitution is a basic law. It is the highest law where the regulation beneath it must be sourced from the constitution; accordingly, no regulations must be contradictory with the constitution.

The supervisory legal politics will be highly determined by political law formation and political law determination. Political law of supervision will be highly determined by political law formation and political law determination. Indonesia has experienced vicissitudes of democracy based on the validity period of the constitution, which has undergone several amendments. At the very least, Indonesia has experienced the phase of the 1945 Constitution, the Federal Republic of Indonesia (RIS) Constitution 1949, the Provisional Constitution 1950, then the 1945 Constitution after the issuance of the Presidential Decree of July 5, 1959, and finally the phase of the enactment of the 1945 Constitution after the amendment.

Indonesian constitutional politics which becomes the most highlighted aspect is the phase of the 1945 Constitution enactment post-Presidential Decree of Jul 51959 and 1945 Constitution post-amendment. The 
constitutional politics on the enactment period of the 1949 RIS Constitution and the enactment period of 1950 provisional Constitution did not get much attention. At least there are two reasons why constitutional politics during the RIS Constitution of the 1949 and during the Provisional Constitution of 1950 did not get that much attention. First, the validity period of the 1949 RIS Constitution and the 1950 Provisional Constitution only applies briefly. The RIS 1949 Constitution was only valid for one year and the Provisional Constitution of 1950 was only valid for less than 10 years. The 1949 RIS Constitution was formed because there was pressure from allies to form a union state. The Provisional Constitution of 1950 was formed with a provisional purpose. Nonetheless, in the state administration during the Constitution, 1950 had left historical scars because at that time there had been a lack of good political stability due to the frequent vicissitudes of the government. Second, the 1945 Constitution and the 1945 Constitution after the constitutional amendment is an inseparable unit. The 1945 Constitution as the results of the amendment is the revision results of the 1945 Constitution. Therefore, to trace the political law of supervision especially by legislative then it should be started from the 1945 Constitution prior to the amendment.

Before the amendment occurred on the 1945 Constitution, The House of Representatives should have sufficient authority to supervise the actions of the President. Members of the House of Representatives are part of the members of the People's Consultative Assembly. The People's Consultative Assembly is a determinant of state direction that must be carried out by the President. The House of Representatives has the authority to oversee every policy of the President whether in line with or not with the direction of the state set by the People's Consultative Assembly.

The House of Representatives according to 1945 Constitution before the amendment indeed had the authority t conduct a supervision on the governmental regulations; however, the regulation on the authority of the House of Representatives to conduct supervision on the governmental regulations is only regulated in the description of the 1945 Constitution, not in its articles. The authority of the House of Representatives in supervising Government policies is also not explicitly stated regarding the type of supervision. There is no explicit mention of whether the type of supervision of the House of Representatives is the right of inquiry, interpellation rights or the right to express opinions. Regulations regarding the authority of the House of Representatives in carrying out supervision are still general.

The type of the House of Representatives' supervisory authority is specifically regulated in the Constitution No. 16 of 1969 on the Structure and Position of the People's Consultative Assembly, the House of Representatives, and Regional People's Legislative Assembly. The inquiry rights of the House of Representatives are regulated in Article 32 paragraph (1) point c Constitution No. 16 of 1969. Constitution No. 16 of 1969 was then revised with the Constitution No. 2 of 1985

The inquiry rights of the House of Representatives according to the Constitution No. 2 of 1985 would be regulated in the constitution itself, however, until the end of the New Order era, it was not formed. If the inquiry rights law was formed during the New Order then the context would be more appropriate than Law No. 6 of 1954 because after all Law No. 2 of 1985 was born based on the 1945 Constitution which was more patterned by a presidential system than Law No. 6 of 1954 which is parliamentary. The absence of the inquiry rights law to replace Law No. 6 of 1954 in the New Order Period is due to the political configuration in the New order period is authoritarian, where the executive authority cannot be controlled externally by the other nation's institution as the House of Representatives.

After the second amendment of the 1945 Constitution, the inquiry rights of Indonesian House of Representatives obtained an explicit regulation. In Article 20 A paragraph (2) the second amendment to the 1945 Constitution was stated: "in addition to the rights stipulated in other articles of this Constitution, the House of Representatives has interpellation rights, inquiry rights and the right to express opinions." Regulation of inquiry rights in Article 20 A paragraph (3) this is not explained regarding definitive inquiry rights. Article 20 A paragraph (4) states "further provisions concerning the rights of the House of Representatives and the rights of members of the People's Representative Council are regulated in the law." The provisions in Article 20 A paragraph (4) mean that the regulation concerning the oversight function of the House is an open legal policy from the legislators, in this case, it is the government and the House of Representatives.

Several experts of constitutional laws, among them, is Bagir Manan criticized the regulation of the House of Representatives' inquiry rights, such as the inquiry rights in the constitution is an uncommon aspect since the oversight function of the House of Representatives is the characteristics from the parliamentary system. The opinion of Bagir Manan is related to the agreement of Ad hoc I committee The People's Consultative Assembly, one of which is to reinforce the presidential system. The aim is to reinforce the presidential system because at the time of the enactment of the 1945 Constitution before the amendment, Indonesia also embraced an impure presidential system. This paper will discuss the exact or not regulation of the House of Representatives' inquiry rights in the Constitution, which adheres to the presidential system. Therefore, this paper is entitled "The legal politics of inquiry rights of the House of Representatives of the Republic of Indonesia after the Amendment to the 1945 Constitution" 


\section{LEGAL MATERIALS AND METHODS}

This research traced the political law of The House of Representatives' inquiry rights contained in the 1945 Constitution after the amendments. The object to be examined in this study is the legal politics of the inquiry rights of the House of Representatives after the amendment to the 1945 Constitution. Based on the research objects, this research is based on the positive law. The object studied in this research is the research in the field of constitutional law.

Based on the research objects above, then the type of this research is normative or legal research. Legal research is a process to find a legal regulation, legal principles, and legal doctrines to answer the encountered issues. This is based on the prescriptive characteristics of legal science.

This legal research employed six approaches, namely:

1) Constitutional regulations Approach

2) Conceptual Approach

3) Historical Approach

4) Political Approach

5) Comparative approach

A statute approach is an approach using legislation and regulation. Thus, the legal approach used in this study starts from the 1945 Constitution to the Regulation of the People's Representative Council of the Republic of Indonesia concerning the Standing Orders of the People's Representative Council of the Republic of Indonesia. Furthermore, the conceptual approach, it is based on a concept undescribed in the constitutional regulations. As mentioned in Article 79 paragraph (3) Constitution Number 17 of 2014, it states that the inquiry rights as mentioned in paragraph (1) point $b$ mentioned the rights of the House of Representatives to conduct an investigation of the implementation of a law and/or Government policy related to important, strategic and broad impacts on the life of the community, nation and state are allegedly contrary to the laws and regulations. There is a concept that has not received information in the Article, namely the concept of policy. Thus, the concept of this policy will be examined using legal principles. Next is a Historical Approach. In this historical approach, this study traces the laws and regulations concerning the House of Representatives' inquiry rights that have been in effect until now. Starting with the RIS Constitution, the 1950 provisional constitution, the Constitution No. 6 of 1954 to the Constitution No. 17 of 2014, the political approach in this research revealed the legal issues using a political perspective because the occurring constitutional dynamics are not only influenced by the legal factor but also influenced by the nonlegal factor namely the political factor.

Another approach is the comparative approach. The comparative approach is meant for finding the fundamental of the inquiry right regulation in the 1945 Constitution. The comparative approach is used to compare the similarities and differences in the arrangement of inquiry rights between the State of Indonesia and other countries, especially the United States and the United Kingdom. The selection of the United States is due to it is being the oldest country running the presidential system. Meanwhile, the selection of The United Kingdom is by the consideration that The United Kingdom is the oldest country implementing a parliamentary governmental system.

As the consequence of normative legal research, then the legal materials used in this study are primary legal materials, secondary legal materials, and tertiary legal materials (non-legal). In normative research, the legal material is very important. Primary legal materials are in the form of legislation, secondary legal material are in the form of journals, books, papers, and the internet, while the tertiary law is a dictionary.

a. The primary legal materials in this research are the legal materials, which become the focus in conducting the research. The legal materials include:

1) The 1945 Indonesian Constitution, Article 20 A paragraph (3)

2) The 1949 Federal Republic of Indonesia (RIS) Constitution, Article 121

3) The 1950 provisional Constitution, Article 70

4) Law Number 6 of 1954 on the decree of the House of Representatives' inquiry rights

5) Law Number 16 of 1969 on the structure and position of People's Consultative Assembly, the House of Representatives, and the Regional Representative Council, Article 32 paragraph 1 point c

6) Law Number 2 of 1985 on the amendment of the Law Number 16 of 1969 on the structure and position of People's Consultative Assembly, the House of Representatives, and the Regional Representative Council, Article 32 paragraph (1) point b

7) Law Number 4 of 1999 on the structure and position of People's Consultative Assembly, Article 33 paragraph (3) point b

8) Law Number 27 of 2009 People's Consultative Assembly, the House of Representatives, and the Regional Representative Council, Article 77 paragraph (1) b and paragraph (3)

9) Law Number 17 of 2014 People's Consultative Assembly, the House of Representatives, and the Regional Representative Council, Article 79 paragraph (1) b and paragraph (3) 
b. The secondary legal materials are the legal materials supporting and strengthening the primary materials which include:

1) Treatise on the court of People's Consultative Assembly and the House of Representatives

2) The opinions of constitutional legal and political-legal experts

3) The literary books of the constitutional law, administrative law, and political law

4) Dissertation, Thesis or research report

5) Articles and paper

6) Internet

c. The tertiary legal materials (non-legal) are the legal materials supporting the primary and secondary legal materials. The tertiary legal materials include

1) Dictionary of law

2) Dictionary of language

\section{III.RESULT AND DISCUSSION}

To understand the legal politics of the House of Representatives' inquiry rights post amendment of the 1945 Constitution, it is better to understand the definition of the legal politics first. After understanding the meaning of legal politics, the next step is to examine the legal politics contained in the 1945 Constitution due to the amendment. Quite a number of experts provide an understanding of legal politics, but from the many definitions or definitions given by legal experts, there is a core of similarity in providing an understanding of legal politics. The similarity is on the fact that legal politics is a planning of law formation to achieve the nation's objectives.

The legal politics mentioned by many experts is a positive legal politics. The positive law here means the law formed by the authorities. Both include the fundamental regulation that is the constitution and other legal products that are legislation and regulation. The selection of legal politics establishment focuses on the establishment of positive legal politics as seen in Article II Transitional Rules, which state, "All state agencies and existing regulations are still in the term, as long as they have not been held according to this Constitution."

The function from this transitional regulation is to anticipate so that there is no vacuum of law post the independence because it is impossible for Indonesia to create a positive law in a relatively short time, so colonial inheritance laws like Burgelijk Wetboek (Civil Code) and Wetboek Van Strafrecht (Criminal Code) remain in force. The validity of colonial laws is based on Article II, the transitional regulation signifies that the choice of legal politics chosen by Indonesia is a positive legal politics.

The amendment of the 1945 Constitution affected on the alteration of legal politics although the main fundamental of legal politics is national laws, namely the opening of the 1945 Constitution has not encountered amendment. The opening of the 1945 Constitution only regulates Indonesia's legal political framework globally, as Indonesia is a sovereign state. The opening of the Constitution only talks about the direction of the country's objectives in general. The preamble of the Constitution does not discuss the authority of national institution and the distribution.

The regulation of the national institution's authorities is regulated in the Constitution. Generally, the Constitution regulates on two aspects namely the distribution of authorities and the acknowledgment of fundamental rights. The form of separation/division of authority will greatly determine the style of the government system adopted by a country. Countries that choose to adopt a presidential system of government prefer to apply consistently the doctrine of separation of authorities compared to a state that adheres to a parliamentary system. The United Kingdom, which is the mother of a parliamentary system, does not adhere to the doctrine of the separation of authorities but adheres to the teachings of the parliamentary supremacy. In The United Kingdom, the parliament can do anything except one thing, that is to make a male as female and vice versa, besides that the parliament can do anything.

The process of the amendment on the 1945 Constitution is based on the agreement of the committee of Ad hoc the Indonesian People's Consultative Assembly in which one of them is to strengthen the presidential system. The commitment to reinforce the presidential system implies that the 1945 Constitution prior to the amendment actually had adopted a presidential system but it was not strict. Therefore, some Indonesian constitutional law experts say that before the 1945 Constitution underwent an amendment, Indonesia adopted a mixture of the presidential systems and parliamentary systems. The characteristics of the presidential system can be seen from the regulation of the presidential authorities in assigning and dismissing the minister while the characteristics of the parliamentary system can be seen by the existence of the People's Consultative Assembly as the highest national institution and the presidential responsibility system is on the People's Consultative Assembly.

The president's responsibility on the People's Consultative Assembly is based on the state policy as determined by the constitution and People's Consultative Assembly. The State Policy stipulated by the Constitution is the authority of the President as stipulated in the Constitution. Meanwhile, the country's direction set by the People's Consultative Assembly was in the form of broad outlines of the country's direction. The outlines of the country's direction are set by the People's Consultative Assembly and then the guidelines of this country's 
policy are carried out by the President and the implementation of the outlines of state policies will be held responsible by the president before the People's Consultative Assembly in the end of the service period because president is assigned and chosen by the People's Consultative Assembly so that the president must conduct the regulations as determined by the People's Consultative Assembly.

The implementation of the state policy outlines by the president will obtain a supervision from the House of Representatives whose members are the part of the members of the People's Consultative Assembly. The authorities of the House of Representatives in conducting the supervision on the president are regulated in the 1945 Constitution. In the elucidation of the 1945 Constitution, it is not specifically regulated regarding the form of supervision from the House of Representatives. If seen from the model of supervision carried out by the House of Representatives to the President it is interpellation rights not an inquiry rights. The fundamental difference in interpellation rights and inquiry rights lies in the object being monitored. Inquiry rights have wider coverage than interpellation rights. The interpellation rights or the right to seek information from the House of Representatives are limited to the supervision of government policies that are political in nature, such as the President's policy in raising fuel prices. The inquiry rights or the rights to conduct an investigation by the House of Representatives is not only limited on the supervision in the governmental regulation related to politics but also can be used in the investigation of legal cases particularly criminal law.

The interpellation rights of the House of Representatives during the New Order is on the strategic position because the political responsibilities on the New Order era are institutional, which is by the president to president. Political responsibility is a form of demand for responsibility by an institution that assigns tasks to subordinates to the subordinates who carry out the task. Political oversight will greatly depend on the political support of the President by political forces in parliament. During the New Order, President Soeharto controlled almost all factions of the political forces in the parliament, both in the House of Representatives and in the People's Consultative Assembly. Based on Law Number 16 of 1969 concerning the Structure and Position of the People's Consultative Assembly, the House of Representatives and the Regional People's Legislative Assembly, most members of the Consultative Assembly are filled with mechanisms for appointment by the President not through General Elections. The cooptation performed by the president on the House of Representatives and the People' Consultative Assembly makes the House of Representatives is not capable of performing the supervision to the president, so that it can be said that in 0 years of Soeharto's reigned, the House of Representatives never conducted a significant supervision.

The inquiry rights were used by the House of Representatives post-Soeharto's Regime on the governance of Abdurrahman Wahid (Gus Dur). The inquiry rights during Gus Dur's administration were carried out by the House of Representatives to investigate Gus Dur's alleged involvement in the Bulog corruption scandal and grant funds from the Sultan of Brunei. The use of the House of Representatives' inquiry rights to alleged corruption and the Brunei Sultan's grant funds resulted in the termination of Gus Dur from the Indonesian presidency. Constitutionally, the House of Representatives' inquiry rights on the suspected cases of corruption in Bulog funds and the Brunei Sultan's grant funds could not result in Gus Dur's termination from the position of President.

The House of Representatives' inquiry rights during the Gus Dur era was conducted when the 1945 Constitution has encountered amendment, however, the amendment in the Gus Dur's governance was not completed. Amendment to the 1945 Constitution during Gus Dur's reign was still in the second amendment, while amendments to the 1945 Constitution occurred four times. The inquiry rights of the House of Representatives to the new President can have implications for the process of dismissal of the President when in the third amendment to the 1945 Constitution, exactly on the borne of the Article 7 A and 7 B, which regulate on the process of President termination.

Before the implementation of the third amendment of the 1945 Constitution, the implication of the use of the House of Representatives' inquiry rights cannot be ended on the process of president's termination. The type of supervision of the House of Representatives of the Republic of Indonesia before the third amendment to the 1945 Constitution, which could result in the termination of the President, is the right of interpellation. The second amendment of the 1945 Constitution related to the oversight function of the House of Representatives merely regulating the interpellation rights, inquiry rights, and the rights to express opinions.

This reason for the inability to terminate Gus Dur as the Indonesian President is due to the involvement in the corruption of Bulog's budget and the Brunei Sultan Grant budget. It is because Gus Dur's position is as the mandate of the People's Consultative Assembly so that only political reasons and not legal reasons can be used as a basis for the People's Consultative Assembly to dismiss the President. The practice of terminating Gus Dur from the position of the President because there was a meaning of the position and authority of the People's Consultative Assembly. Ismail Suny stated that the Indonesian Constitutional system prior to 1945 constitutional amendment adhering to the supremacy of the People's Consultative Assembly.

The position of the People's Consultative Assembly as the highest national constitution according to Ismail Sunny signifies that 1945 constitution prior to amendment adhering to the People's Consultative Assembly supreme system. The argument of Ismail Sunny is based on two things, namely: 
1. The sovereign body has a "legal authority", power based on the law to determine everything that has been affirmed by the constitution, for example according to the 1945 Constitution: to establish constitutions and outlines of state policy (article 3), to elect a president and vice president (article 6), and to amend the constitution (article 37);

2. Besides that, there is no rival authority both private and institution which has an authority to violate or put aside something that has been decided by the sovereign body.

The statement of Ismail Sunny is strengthened by the description in Article 31945 constitution which states that because the People's Consultative Assembly holds the sovereignty of the state, then its authority is unlimited. "Literally the formulation of the explanation of article 3 can be interpreted that the People's Consultative Assembly can do anything. "The authority of the People's Consultative Assembly is not limited to any authority or anything.

It is known that the legal politics of the 1945 Constitutional amendment, one of them is to emphasize on the presidential system. The characteristics of the presidential system do not have one state institution that is higher than other state institutions. The presidential system is a system that refers to the teaching of separation of authorities. The consequence from the teachings of the separation of authority is that there is no single dominant state institution against other state institutions.

The regulation on the political supervision as inquiry rights by the House of Representatives on the Government are performed by several experts is contradictory with the spirit of presidential system. The presidential system rooted in the doctrine of the separation of authorities makes it impossible for inter-state institutions to interfere with each other. This is different from a parliamentary system in which the parliament has a higher position among other state institutions so that parliamentary consequences can be freely interfered with in the authority of other state institutions. Meanwhile, there are also experts who argue that arrangements regarding political oversight by the House of Representatives in countries that embrace the presidential system are natural.

To sharpen the analysis on the political supervision of the House of Representatives, particularly the inquiry rights in the presidential system, then in this writing the comparative method was employed on the regulation of political supervision by the House of Representatives in three countries namely the USA, The United Kingdom, and Netherland. Countries that will be used as comparisons are the United States, The United Kingdom, and the Netherland. The United States is one of the countries that are compared because the United States is a country that is the main reference for reviewers of constitutional law and political science related to the presidential system of government. Meanwhile, The United Kingdom was used as a reference in the comparison of inquiry rights because The United Kingdom was the first country to adopt a parliamentary system. Netherland is a reference in this comparison because however, Indonesia has a historical bound with the Netherland.

1. Inquiry Rights in the United States

The popular US congress authority is the authority in formulating the constitution. The authority of Congress in supervising the performance of the Government can be said to be less popular with the authority of the parliament in countries that adhere to a parliamentary system. However, it does not mean that the United States Congress does not have the authority to supervise the Government. The authority of the US congress $\mathrm{n}$ performing the supervision on the Governmental regulations is known as Congressional Oversight.

The authorities in conducting the supervision on the governmental regulation are indeed not regulated strictly in the Constitution. The authorities of Congress is an integrated part of the US check and balance system.

The objectives of Congressional Oversight are as follows:

1. Increasing the efficiency, economy, and effectiveness of the governmental operation

2. Evaluating the government's program and performance

3. Detecting and preventing bad administration waste, abuse, arbitrary and changing behavior, or illegal and unconstitutional behavior;

4. Protecting civil freedom and citizens' constitutional rights;

5. Giving knowledge to the public and making sure that the executive regulation reflects the public interests.

6. Collecting information to develop the new constitutional proposal or to revise the existing constitution;

The authority of Congress in conducting the supervision is included in the category of conducting an investigation. Although not regulated strictly in the Constitution, the authority of Congress is relatively significant. The acts of government can be supervised by the government through the standing committees, both in the designated House of Representatives and Senate "(to) exercise continuous of the executive by the administrative agencies of any laws, the subject matter of which is within the jurisdiction of such committees.

The not strictly regulated Congress' authority in conducting supervision and investigation, then it can be concluded that the congress authority in conducting supervision and investigation falls into the category of constitutional conventions. In the constitutional system in the United States, it is also known the role of the constitutional convention, even though it is not as strong as the state administration system.

Another form of the constitutional convention in the United States is judicial review. The practice of judicial review originated from the Marbury vs Madison dispute handled by Chief Justice John Marshall. Thus, in the constitutional system in the United States, constitutional conventions are recognized as one of the sources of United 
States constitutional law, including the practice of Supervision by the Congress of the Government.

Different from the committee in other countries' parliament, the congressional committees are autonomous, having its own budget and staffs. Besides that, the committee can conduct hearing themselves and other people are required to come and if needed they are forced to come. The way it works is aggressive and the results of its investigations are widely reported in the mass media. In addition, in the context of the discussion of the Draft Law, the Congress held a hearing with the nuances of the investigation.

In 2016, precisely during the Presidential election in the US, the US Congress would conduct an investigation related to the use of personal email for official state affairs. At that time, Hillary Clinton served as Foreign Minister in the administration of President Barrack Obama. The use of personal email accounts for official state affairs violates US federal laws

2. The Inquiry Rights in The United Kingdom

The development of Inquiry rights in the English parliamentary is tremendously strong. This is because the judicative institution in The United Kingdom does not develop well. All policies are taken by the government and are considered contrary to the laws submitted to parliament. This kind of the parliamentary act is considered a projection in The United Kingdom. The Special Force (Pansus) for inquiry rights in the country also has a strong position and is protected by the state. It cannot be dissolved for any reason. Even though one day the British Queen would like to dismiss the parliament, then a special force of the inquiry rights are maintained.

The use of the inquiry rights in The United Kingdom is because of the existence of the House of Representatives selected through the public election in the parliamentary system representing democracy and people's sovereignty. Therefore, aside from being authorized to choose and form a government, they also supervise and at any time can hold the government accountable, both jointly and individually according to each field of expertise.

The mechanism causes the governmental position period both jointly or individually is not permanent and periodically can be stopped during the service period if the parliament assesses and gives a motion of noconfidence on the governmental work performance. Therefore, the use of inquiry rights by the parliament in the UK as a form of the parliamentary oversight of the Government's performance and can result in a vote of no confidence.

The oversight function of the cabinet is conducted more by the House of Commons. However, House Of Lords has five types of authorities, including in the fields of justice, constitution, finance, executive, and constitutional. The authorities of the House of Lords in conducting the supervision in the executive policies are included in the executive authorities.

The institutionalization of inquiry rights emerged in The United Kingdom in the middle of the XIV century was initiated by the investigation rights and chastise the abuses of administration (the right to investigate and punish abuses in government administration) which was then called the right of impeachment (the right to prosecute and resulted in several court officials being dismissed for financial fraud. Therefore, the first inquiry right is in the financial field, (financial enquete), then spread out to the political enquete, legislative enquete, and election enquete.

3. The Inquiry rights in Netherland

Netherland is a unitary state, namely a sovereign state held as a single entity, that the central government is the highest government, its subnational units only exercise the powers chosen by the central government to be delegated. The state government basically, consists of three main institutions, namely the queen, the council of ministers, and the parliament (state general). The Dutch Parliament consists of Eerste Kamer (Senate) and Tweede Kamer (DPR).

The governmental system of the Netherland Monarchy is parliamentary. Therefore, the parliament has the authority to appoint the prime minister. Parliament can also bring down the government by issuing a vote of no confidence. The constitution in force in the Netherland is the Constitution of 1848, which is designed by the constitutional legal expert Thorbecke. The Netherland Constitution focuses on the Society's authority.

The constitutional amendment of the Netherland Monarchy occurred several times, which were in 1814, 1848, and 1972. In Article 70 of Netherland Constitution, parliament has an authority to conduct enquete constitutionally.

The Article 70 in Netherland Constitution states that:

"The two Houses shall jointly and separately have the right of inquiry (enquête) to be regulated by Act of the Parliament."

Both chambers in the parliament can conduct jointly or individually an investigation.

The Netherland parliament conducted the last investigation in 2012 related to the sexual harassment and violation cases occurred in the Catholic Church environment. The direct investigation is the biggest discovery method ever carried out by parliament. Only ten of the best investigations ever carried out by the Dutch parliament since World War II. Opposition MPs conducted an investigation based on the reason that the government's actions in handling this case were unsatisfactory

Based on the comparison from several countries, including the country adopting the presidential system, 
namely the United States and the countries that adhere to a parliamentary system, namely the United Kingdom, and the Netherland, the authors can extract the basic differences between the countries above from Indonesia which are based on 1945 Constitution post-amendment in the field of the parliamentary supervision, specifically inquiry rights. The differences are as follows:

1) The United States of America, the United Kingdom, and Netherland in conducting inquiry rights (inquiry) involve both rooms. In America, which has the authority is Congress through the Committee of Investigators. Meanwhile, in the United Kingdom even though the main oversight function is House of Commons, House of Lords also has authority in the executive field which actually also functions to supervise government policies. In Netherland, the authority to conduct an investigation is performed by two chambers namely Tweede Kamer and Eerste Kamer.

2) In Indonesia, the authority to conduct a supervision especially the inquiry rights is only performed by the House of Representatives.

To be clearer, the differences of investigation rights in Indonesia, the United States, The United Kingdom, and Netherland can be seen in the table below.

\begin{tabular}{|c|c|c|c|c|c|}
\hline \multicolumn{6}{|c|}{ The Comparison of Investigation Rights in The United States, The United Kingdom, Netherland, and Indonesia } \\
\hline No. & $\begin{array}{l}\text { Investigation } \\
\text { Rights }\end{array}$ & Indonesia & The United States & $\begin{array}{l}\text { Inquiry Rights in } \\
\text { The } \\
\text { Kingdom }\end{array}$ & Netherland \\
\hline 1. & Nomenclature & Inquiry Rights & $\begin{array}{l}\text { Congressional } \\
\text { Oversight }\end{array}$ & $\begin{array}{l}\text { Parliamentary } \\
\text { Investigation }\end{array}$ & $\begin{array}{l}\text { Parliamentary } \\
\text { Investigation }\end{array}$ \\
\hline 2. & Regulations & $\begin{array}{l}\text { Regulated strictly } \\
\text { in Article } 20 \text { A } \\
\text { paragraph } \\
\text { Indonesian } \\
\text { Constitution of the } \\
1945\end{array}$ & $\begin{array}{l}\text { Not strictly regulated } \\
\text { in the Constitution. } \\
\text { Only As a } \\
\text { Consequence Against } \\
\text { Check And Balances } \\
\text { Between } \\
\text { Branches Three } \\
\text { Authority, Namely } \\
\text { Legislative, } \\
\text { Executive } \\
\text { Judicial and } \\
\end{array}$ & $\begin{array}{l}\text { Based on the } \\
\text { constitutional } \\
\text { convention }\end{array}$ & $\begin{array}{lr}\text { Regulated } & \text { in } \\
\text { Article } & 70 \\
\text { Netherland's } & \\
\text { Constitution } 1848\end{array}$ \\
\hline 3. & Conducted by & $\begin{array}{l}\text { The House of } \\
\text { Representatives }\end{array}$ & Congress & $\begin{array}{l}\text { Mainly conducted } \\
\text { by the House Of } \\
\text { Commons but } \\
\text { House Of Lords } \\
\text { also has the } \\
\text { supervisory } \\
\text { authority }\end{array}$ & $\begin{array}{l}\text { The Dutch } \\
\text { Parliament is both } \\
\text { separately, that is, } \\
\text { only the lower } \\
\text { house or lower } \\
\text { house can jointly } \\
\text { conduct an enquete } \\
\text { on Government } \\
\text { policies. }\end{array}$ \\
\hline
\end{tabular}

Source: Author's creation

From the description of the table above, the fundamental differences of regulations can be seen between the investigation rights in Indonesia and the three countries being compared, namely, the United States, The United Kingdom and the Netherland lie in their institutional authority. Congressional Oversight in the United States, which has authority, is Congress. Thus, the authority to conduct an investigation is in the hands of the two chambers of Congress, namely the House of Representative and Senate together. Meanwhile, in the UK the authority to carry out the main investigation is in the hands of the House of Commons, although the House of Lords also has the authority to conduct a supervision on the government's work performance. In Netherland, the investigation authority is conducted individually both by each chamber and jointly.

The regulation of investigation rights in Indonesia places the authority on the House of Representatives. The placement of investigation rights authority to the House of Representatives is because one of the political laws of the 1945 Constitution is to strengthen the DPR, especially in the aspect of its authority. The political law according to the post-amendment 1945 Constitution aims to strengthen the DPR without any intention to strengthen the Regional Representative Council (DPD). The dominance of the DPR against the DPD can be seen in Article 22 D. In Article $22 \mathrm{D}$, the Regional Representative Council only has a weak legislation function.

Article 22 D paragraph (3) The Regional Representative Council (DPD) was given the authority o conduct the supervision on the implementation of the constitution related to regionalism, however on how the supervision is conducted is still limited. Seen in Article $20 \mathrm{~A}$, then the authority of DPD is not included in the category of interpellation rights, inquiry rights, and the rights to express opinions. 
According to Mohammad Fajrul Falaakh, the formulation of articles in the 1945 Constitutional amendment that tends to strengthen the function of the DPR on the one hand and does not strengthen the function of the DPD, on the other hand, is a form of legislative heavy. An example is an emergence of a reactive formula in Article 7C which states "President cannot confine and/or dismiss the House of Representatives. The formulation can raise questions on whether the dismissal on DPD is allowed".

The granting of authority on the implementation of the parliamentary supervision to the government only to the House of Representatives is surely inseparable from the aspect of Indonesian constitutional history. Indonesia at the time of the enactment of the 1950 Constitution that adopted a parliamentary system laid the authority to carry out inquiry or inquiry rights only to the DPR. This is reinforced by the birth of law no. 6 of 1954 concerning the Determination of Inquiry Rights, in which the DPR has the right to exercise inquiry rights. The Federal Republic of Indonesia (RIS) in which the form of the country adopts the federal or united nation also places the authority to conduct only to the House of Representatives.

\section{IV.CONCLUSION AND SUGGESTIONS}

The regulation of the House of Representatives' inquiry rights in the 1945 Constitutional amendment is not contradictory with the spirit of strengthening the presidential system. The United States has been a reference in the implementation of the presidential system, which also has an oversight function similar to the inquiry rights. The oversight function of the United States representative institutions in conducting investigations into Government policies is known as the Congressional Oversight. Thus, the regulation of the inquiry rights of the Indonesian House of Representatives after the amendment to the 1945 Constitution does not contradict the spirit of presidential system strengthening. There is a difference between the regulation of the House of Representatives' inquiry rights in Indonesia after the Amendment to the 1945 Constitution and the Congressional Oversight in the United States. The authority of inquiry rights in Indonesia is only owned by the House of Representatives, while the Congressional Oversight of its authority is carried out by Congress. There are at least two reasons that Indonesia has only put the authority of inquiry rights to the House of Representatives. First, the structure of the Indonesian parliament after the amendment to the 1945 Constitution did not adhere to the bicameral system. Second, from the historical aspect, the regulation of inquiry rights is always attached to the authority of the House of Representatives. Both arrangements are through the 1949 RIS Constitution and the 1950 Provisional Constitution. The research results suggest that the House of Representatives conducts their supervision through the inquiry rights. They should only use the inquiry rights on the government's regulation that is significantly related to the important regulation or related to the violation of criminal law and despicable acts as stipulated in Article 7 A of the 1945 Constitution of the Republic of Indonesia. Meanwhile, if merely related to the political regulations, the House of Representatives should use the interpellation rights.

\section{REFERENCES}

A.S.S. Tambunan. 2001. Hukum Tata Negara Perbandingan. Jakarta. Puporis.

Bagir Manan. 2012. Membedah UUD 1945. Malang UB Pers.

Donald A. Rumokoy. 2011. Praktik Konvensi Ketatanegaraan di Indonesia. Jakarta. Media Prima Aksara.

Halchin, L. Elaine dan Kaiser, M Frederick. 2012. Congressional Oversight. USA. Congressional Research Service.

Imam Syaukani dan A Ahsin Thohari. 2015. Dasar-Dasar Politik Hukum Indonesia, Jakarta. Rajawali Pers.

Ismail Sunny. 1977. Mekanisme Demokrasi Pancasila. Jakarta. Penerbit Aksara Baru.

Johnny Ibrahim. 2013. Teori \& Metodologi Penelitian Hukum Normatif, Malang. Bayumedia Publishing.

Miriam Budiardjo. 1995. Dasar-Dasar Ilmu Politik. Jakarta. PT Gramedia Pustaka Utama.

Mohammad Fajrul Falaakh. 2014. Pertumbuhan Dan Model Konstitusi, Yogyakarta. Gajah Mada. University Press.

Peter Mahmud Marzuki. 2005. Penelitian Hukum. Jakarta. Kencana Prenada Media Group.

The 1945 Indonesian Constitution

The 1949 Federal Republic of Indonesia (RIS) Constitution

The 1950 provisional Constitution

The Dutch Constitution

Law Number 6 of 1954 on the decree of the House of Representatives' inquiry rights

Law Number 16 of 1969 on the structure and position of People's Consultative Assembly, the House of Representatives, and the Regional Representative Council

Law Number 2 of 1985 on the amendment of the law Number 16 of 1969 on the structure and position of People's Consultative Assembly, the House of Representatives, and the Regional Representative Council

Law Number 4 of 1999 on the structure and position of People's Consultative Assembly

Law Number 27 of 2009 People's Consultative Assembly, the House of Representatives, and the Regional Representative Council 
Law Number 17 of 2014 People's Consultative Assembly, the House of Representatives, and the Regional Representative Council

https://internasional.kompas.com/read/2015/03/05/10014401/Kasus.E-

mail.Pribadi.Clinton.Akan.Diselidiki.Kongres.AS , accessed on 1 April 2018 